\title{
Attitude towards Women's Employment: A Review after 15 Years
}

\author{
Dr Moly Kuruvilla ${ }^{1}$, Seema S P \\ ${ }^{1}$ Associate Professor, Centre for Women's Studies, University of Calicut, India \\ ${ }^{2}$ Research Scholar, Centre for Women's Studies, University of Calicut, India
}

\begin{abstract}
While on the global scenario, women workforce is considered as a key to the economic growth of $21^{\text {st }}$ century, the economic participation of women in India and especially that of Kerala is far from satisfactory. In spite of their better status and position with regard to literacy, educational standards and health indicators compared to other parts of the country, women of Kerala have low levels of participation in economic activity. A study on the attitude towards women's employment on a sample of 360 employees and students conducted in University of Calicut in the year 1998 revealed the positive attitudes of women students and employees and the negative attitudes of men students and employees towards women's employment. When the study was repeated after 15 years, results showed a significant positive trend. Female students and employees showed a highly favourable attitude towards employment of women as in the previous study. Male employees showed a significant positive change while the male students still have a negative attitude towards women's employment. In order to change the deep rooted perceptions regarding gender roles and life goals of women, effective interventions in the socialization process in favour of women's emancipation is required.
\end{abstract}

Keywords: Attitude towards women's employment, Work participation rate, Gender role perception, Workfamily conflict, Spousal support.

\section{Introduction}

Empowerment of women has been identified as a major footstep towards attaining sustainable development by different economic and social world organizations and nations around the world. Recognizing the need, the Government of India has introduced several women empowerment programmes, which brought about considerable changes towards advancement, development and empowerment of women. India's National Policy for the Empowerment of Women, 2001 perceived the need for increased space for women in decisionmaking, economic and social policies, enhanced opportunities and gender equality in the fields of education, health, etc. and prescribed to achieve the goal by 2010. The specific goals of the Policy stress the need to attain equal participation in decision-making in social and economic life, to enable women to identify their full potential, equal access to quality education, career-guidance, employment, health and safety and changing societal attitudes and community practices. But the goals specified by the National Policy are yet to be achieved.

Increasing women's participation in the economy is considered as a critical source of growth for countries around the world in the $21^{\text {st }}$ century and improved work participation is conceived as an indicator of women's improved status in the society. One third reservation for women in the Panchayati Raj Institutions as per the $73^{\text {rd }}$ amendment of the Indian constitution has made remarkable changes in the political and social involvement of women and has enabled them to contribute to the arenas of decision making at the local level. Though the need for economic stability in the family, the changing requirements of the family, the enhanced social space, the urge for higher status in society and the changing life situations have forced more and more women to enter the labour force, the gender division of labour and the increased responsibility assigned to women towards family and childcare restrain women from attaining better education and employment opportunities other than the stereotyped patterns. The processes of globalization and accompanying modernization and industrialization have introduced dramatic changes in the social and economic conditions of women in India. Globalization has brought about increased job opportunities, especially to women, whether highly educated or not, and let them enter into the various fields of productive economy.

The state of Kerala offers interesting paradox of social advancement and economic stagnation of women. Women, in spite of their better status and position with regard to literacy, educational standards and health indicators compared to other parts of the country, have low levels of participation in economic activity [1]. Table I shows a comparison of the female literacy and work participation rates of Kerala [2] and India [3] as have been revealed by the Census reports of the years 1991, 2001 and 2011. 
Attitude towards Women's Employment: A Review after 15 Years.

Table I Female Literacy and Work Participation Rates in Kerala/India

\begin{tabular}{|c|c|c|c|c|}
\hline \multirow{2}{*}{ Year } & \multicolumn{2}{|c|}{ Literacy Rate } & \multicolumn{2}{c|}{ Work Participation Rate } \\
\cline { 2 - 5 } & India & Kerala & India & Kerala \\
\hline 1991 & 39.29 & 86.93 & 19.67 & 15.8 \\
\hline 2001 & 54.16 & 87.7 & 22.27 & 15.38 \\
\hline 2011 & 53.7 & 91.98 & 25.63 & 18.23 \\
\hline
\end{tabular}

Source: Census of India 1991, $2001 \& 2011$

In spite of an increased literacy rate and higher education level, the female labour force participation in the State is lower than the national average. Studies have pointed out that gender discrimination in the labour market in terms of occupational sex segregation contributes to the low levels of economic participation among women in Kerala [1]. Educated unemployed in Kerala in general and females in particular is a notable paradox. Preference for salaried stereotyped jobs than self employment, as teachers, medical persons, etc. can be viewed as reasons contributing to this unemployment. Above all, the traditional concepts regarding gender roles and the restricted mobility especially in rural areas also serve as major impediments to women's employment outside home.

It is often found that family organization forms a powerful source of resistance to women's work. The cultural norms insist that women's first responsibility is to her home and hence the course of action women take with respect to her work depends on the adjustments made between the work front and the home. The society arbitrarily believes and assigns certain personality traits, roles and behaviours to men and women. Breaking this calls forth much opposition and alienation from society and hence people rarely dare to do it and women always are the loosers in this division of responsibilities and roles [4]. Working women are expected to cope up with multiple roles and be super women to prove themselves. Lack of spousal support in household chores and childcare as well as providing the necessary emotional support to enable the partner to manage the demands arising from one's participation in multiple roles has been identified as a source of work-family conflict [5].

A growing body of research suggests that women experience a "motherhood penalty" or "child penalty" when they attempt to combine earning and caring. In the study on motherhood, employment and the child penalty, Baker found that employment "choices" vary among women and are shaped by domestic arrangements, perceptions of support, occupational requirements and ideas about "good mothering"[6]. Marriage and parenthood encourage fathers to take their earning obligations more seriously while new mothers often reduce their employment commitments [7] Combining motherhood and paid work is particularly challenging in jobs that require high qualifications, entrepreneurial activities and continued productivity, such as university teaching and research [8], [9].

Desai et al [10] examine the neglected pocket of resistance of married male employees who have stayat-home wives to the gender revolution in the workplace. Their study on 718 married, male participants found that employed husbands in traditional marriages, compared to those in modern marriages, tend to (a) view the presence of women in the workplace unfavourably, (b) perceive that organizations with higher numbers of female employees are operating less smoothly, (c) find organizations with female leaders as relatively unattractive, and (d) deny, more frequently, qualified female employees' opportunities for promotion.

A study on the attitude towards women's employment on a sample of 260 men and women employees and 100 students conducted by Kuruvilla and Usha in University of Calicut revealed the positive attitudes of women students and employees and the negative attitudes of men students and employees towards women's employment [11]. As far as the state of Kerala is concerned, it can be inferred that the social and economic development has not occurred simultaneously. There is a mismatch in the state, between the lower female labour force participation and the higher literacy rate and education standards of women, mainly due to the stereotyped roles ascribed to women. Today after 15 years, the increased literacy rate and educational standards of women along with the increasing job opportunities in the present day context is likely to bring about positive changes in the attitudes of men and women towards women's employment. At the same time, the contradiction of high literacy rate of females and their low work participation rate still exists in the Kerala society according to Census, 2011. It was in this context that the present attempt to repeat the study on a similar sample using the same tool was undertaken to understand whether traditional concepts and subsequent unfavourable attitudes towards women's employment still persist in the society and pose a barrier to the work participation rate of women.

\section{Objectives of the Study}

The present study was undertaken with the following objectives:

1. To compare the attitudes of men and women towards women's employment for the total sample and the sub samples formed on the basis of employee/student and gender.

2. To compare the attitudes of employees and postgraduate students towards women's employment for the total sample and the subsamples based on gender. 
3. To compare the attitudes of the total sample and relevant sub samples of the previous study and the present study.

\section{Hypotheses of the Study}

The hypotheses enlisted for the present study were as follows:

1. There will be significant difference in the attitudes of men and women towards women's employment for the total sample and the subsamples formed on the basis of employee/student and gender.

2. There will be significant difference in the attitudes of employees and postgraduate students towards women's employment.

3. There will be significant difference in the attitude towards women's employment of the total sample and the subsamples in the present study and that of the previous study.

\subsection{Sample}

\section{Methodology}

A total of 360 respondents including 260 employees and 100 PG students of University of Calicut were selected for the present study as has been done in the previous study. The employees include 130 males and 130 females of different categories of posts, ie. gazetted officers, non-gazetted officers, assistants and other employees of University of Calicut. The students of postgraduate level including 50 males and 50 females were selected from different departments of the University. The employees belong to the age group of 25 to 56 and the students belong to the age group of 22 to 30 years. Since the sample was selected randomly, and being a heterogeneous one drawn from people belonging to various districts and socio-economic conditions, the University sample can be considered as a cross section of the educated community of Kerala.

\subsection{Tool}

The tool named 'ATWES' (Attitude Towards Women's Employment Scale) developed by Kuruvilla and Usha [12] was used to collect the data. It is a 40 item three point Likert type scale with five dimensions Individual aspects, Social aspects, Child upbringing aspects, Marital and Familial aspects and Work related aspects. The validity of the scale is 0.67 , the odd even reliability is 0.94 and the test - retest reliability is 0.90 . The validity and reliability indices of the scale indicate that the scale gives appropriate measure of attitude towards employment of women. There are 18 positive items and 22 negative items in the scale. The scoring procedure is 2, 1, 0 for the responses Agree, Undecided and Disagree respectively in the case of positive items and the scoring procedure is reversed in the case of negative items.

\section{Results}

5.1 Attitude Towards Women's Employment in Study I.

The findings of the previous study conducted by Kuruvilla and Usha (1999) [11] are given in Table 2.

Table 2 Means, SD's and 't' Values of the Scores of Attitude Towards Women's Employment of the Total Sample and the Sub samples of Study 1

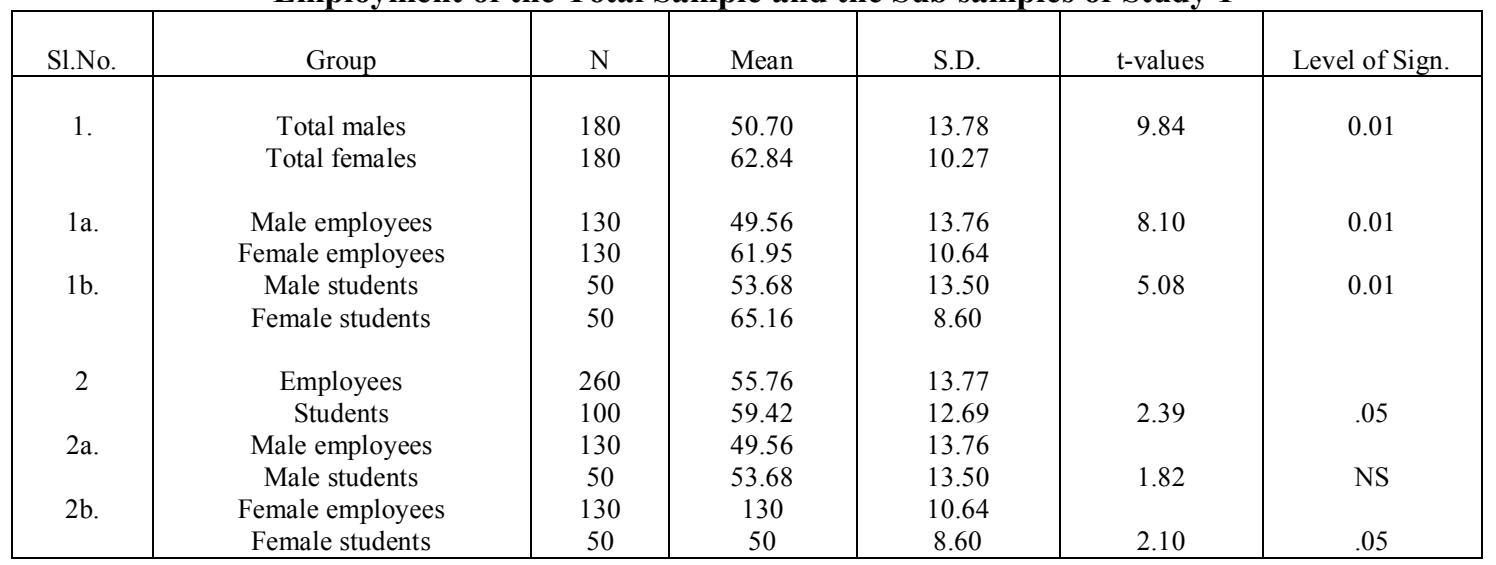

As evident from the table, there was a highly significant difference in the attitude scores of men and women towards women's employment for the total sample with women having higher scores when compared to men. Significant difference at 0.01 level was found in the mean scores of attitude between male and female employees with women employees having more positive attitude towards women's employment. Though a significant difference at .05 level was found between the attitude of employees and students for the total sample and in the case of female employees and female students, no significant difference was found between male 
employees and male students. The female student group showed the most favourable and the male employees group the least favourable attitude towards women's employment.

\subsection{Attitude Towards Women's Employment in Study II}

The findings of the present study using the same tool as that of the previous study are given in Table 3 .

Table 3 Means, SD's and t' Values of the Scores of Attitude Towards Women's Employment of the Total Sample and the Sub samples in Study II

\begin{tabular}{|c|c|c|c|c|c|c|}
\hline Sl.No. & Group & $\mathrm{N}$ & Mean & S.D. & t-values & $\begin{array}{c}\text { Level of } \\
\text { Sign. }\end{array}$ \\
\hline 1. & $\begin{array}{c}\text { Total males } \\
\text { Total females }\end{array}$ & $\begin{array}{l}180 \\
180\end{array}$ & $\begin{array}{l}58.93 \\
63.92\end{array}$ & $\begin{array}{l}17.52 \\
15.79\end{array}$ & 2.88 & 0.01 \\
\hline $1 \mathrm{a}$. & $\begin{array}{l}\text { Male employees } \\
\text { Female employees }\end{array}$ & $\begin{array}{l}130 \\
130\end{array}$ & $\begin{array}{l}59.63 \\
63.21\end{array}$ & $\begin{array}{l}8.50 \\
7.28\end{array}$ & 3.71 & 0.01 \\
\hline $1 b$. & $\begin{array}{l}\text { Male students } \\
\text { Female students }\end{array}$ & $\begin{array}{l}50 \\
50\end{array}$ & $\begin{array}{l}56.84 \\
65.72\end{array}$ & $\begin{array}{c}13.57 \\
9.07\end{array}$ & 3.84 & 0.01 \\
\hline 2 & $\begin{array}{l}\text { Employees } \\
\text { Students }\end{array}$ & $\begin{array}{l}260 \\
100\end{array}$ & $\begin{array}{l}61.42 \\
61.44\end{array}$ & $\begin{array}{c}8.50 \\
12.29\end{array}$ & 0.01 & NS \\
\hline $2 \mathrm{a}$. & $\begin{array}{l}\text { Male employees } \\
\text { Male students }\end{array}$ & $\begin{array}{c}130 \\
50\end{array}$ & $\begin{array}{l}59.63 \\
56.84\end{array}$ & $\begin{array}{c}8.50 \\
13.57\end{array}$ & 1.77 & NS \\
\hline $2 b$ & $\begin{array}{l}\text { Female employees } \\
\text { Female students }\end{array}$ & $\begin{array}{c}130 \\
50\end{array}$ & $\begin{array}{l}63.21 \\
65.72\end{array}$ & $\begin{array}{l}7.28 \\
9.07\end{array}$ & 1.79 & NS \\
\hline
\end{tabular}

The scores of study II reveal that there exist a significant difference at 0.01 level in the attitude towards women's employment between men and women. With regard to the total male employees and the female employees too, a significant difference at 0.01 level was found with female employees having a higher positive attitude towards women's employment. The subsample of male students and female students also show a significant difference at 0.01 level with female students having higher scores in their attitude towards women's employment. But no significant difference was found between the attitudes of the employee and student sub samples. Similarly, no significant difference was found in the attitude towards women's employment of male employees and male students and between female employees and female students.

\subsection{Comparison of Attitude Towards Women's Employment in Study I and Study II}

The data and results of the comparison of attitude towards women's employment of the total sample and the sub samples of Study I with that of Study II are given in Table 4.

Table 4 Means, SD's and' $t$ ' Values of the Scores of Attitude Towards Women's Employment of the University Sample- A Comparison Between Study I and Study II

\begin{tabular}{|c|c|c|c|c|c|c|}
\hline S1.No. & Group & $\mathrm{N}$ & Mean & S.D. & t-values & $\begin{array}{l}\text { Level of } \\
\text { Sign. }\end{array}$ \\
\hline \multirow[t]{2}{*}{1.} & Males-I & 180 & 50.70 & 13.78 & \multirow[t]{2}{*}{4.96} & \multirow[t]{2}{*}{0.01} \\
\hline & Males-II & 180 & 58.93 & 17.52 & & \\
\hline \multirow[t]{2}{*}{2} & Females-I & 180 & 62.84 & 10.27 & \multirow[t]{2}{*}{0.77} & \multirow[t]{2}{*}{ NS } \\
\hline & Females-II & 180 & 63.92 & 15.79 & & \\
\hline \multirow[t]{2}{*}{3} & Employees-I & 260 & 55.76 & 13.77 & \multirow[t]{2}{*}{5.72} & \multirow[t]{2}{*}{0.01} \\
\hline & Employees-II & 260 & 61.42 & 8.10 & & \\
\hline \multirow[t]{2}{*}{4} & Students-I & 100 & 59.42 & 12.69 & \multirow[t]{2}{*}{1.14} & \multirow[t]{2}{*}{ NS } \\
\hline & Students-II & 100 & 61.44 & 12.29 & & \\
\hline \multirow[t]{2}{*}{5} & Male employees-I & 130 & 49.56 & 13.76 & \multirow[t]{2}{*}{7.09} & \multirow[t]{2}{*}{0.01} \\
\hline & Male employees-II & 130 & 59.63 & 8.50 & & \\
\hline \multirow[t]{2}{*}{6} & Female employees- I & 130 & 61.95 & 10.64 & \multirow[t]{2}{*}{1.12} & \multirow[t]{2}{*}{ NS } \\
\hline & Female employees-II & 130 & 63.21 & 7.28 & & \\
\hline \multirow[t]{2}{*}{7} & Male students-I & 100 & 53.68 & 13.50 & \multirow[t]{2}{*}{1.17} & \multirow[t]{2}{*}{ NS } \\
\hline & Male students-II & 100 & 56.84 & 13.57 & & \\
\hline \multirow[t]{2}{*}{8} & Female students-I & 100 & 65.16 & 8.60 & \multirow[t]{2}{*}{0.34} & \multirow[t]{2}{*}{ NS } \\
\hline & Female students-II & 100 & 65.72 & 9.07 & & \\
\hline
\end{tabular}

*Study I conducted by Kuruvilla and Usha (1999) [11]

Table 4 shows a significant difference at 0.01 level between the scores of attitude towards women's employment of the employees in Study I and that of Study II with higher scores for the sample in the second 
study. Similarly the total male samples of Study I and Study II also show a significant difference at 0.01 level in their attitude scores in favour of the sample of Study II. When the mean scores of attitude towards women's employment of the male employees of the two studies were compared,'t value' at 0.01 level significance was obtained with the male employees showing higher positive values in Study II. No significant difference in their attitude towards women's employment was found between the total female sample, total student sample and male students of the two studies. Similarly no significant difference is found in the scores of attitude towards women's employment of female students of Study I and Study II. The most significant difference was found between the scores of attitudes of the male employees of the two studies.

\section{Discussion}

The results of the study show a significant positive trend in the attitude of the University sample towards women's employment. The two subgroups of women in Study II showed a highly favourable attitude towards employment of women. Similar was the case in Study I also. The male employees show a positive change in their attitude towards women's employment whereas no change is seen in the case of the male students. Male employees must have changed their mindset most probably due to the practical approach in their life gained from experiences. The higher cost of living in the present day context necessitates higher income through employment of women. Improved economic status to the family and better living conditions resulting from women's employment might have been experienced by them in their personal lives also.

According to Sharma, some people alert for a simple explanation of the numerous and complex social problems and identify employment of women as the principal cause of current social problems [13]. They include higher divorce rates, more crime and delinquency. Even today, women's employment is considered as a reason for the higher divorce rates and rising atrocities against women. Women's primary duty is still considered as child rearing and housekeeping, and employment is given only the second priority. This message is strongly conveyed to the younger generation through various socialization agencies like media and religion and as a result, the youngsters, particularly boys persist in their belief that maintenance of family and child rearing are the prime responsibilities of girls and women. The defective socialization processes still prevailing in our society sustains the subordination of women and restrains men from considering women as equal citizens. This can be considered as the reason for the unfavourable attitude scores of male students in the sample towards employment of women.

The globalization and modernization programmes flourishing in the State have brought about considerable changes in the attitude of men towards women's employment. But this change is not seen in the case of younger generation as in the sample of men students of the second study. Similar findings were obtained by Kuruvilla in a study on Gender role perception conducted on a sample of 632 students from 20 B.Ed colleges of the state of Kerala [14]. The results of the study revealed significant difference in the gender role perception between boys and girls with girls having highly progressive and boys having traditional perceptions regarding gender roles. Both boys and girls belong to similar age groups and have had the same type of exposure to education. When almost all the women students consider employment as a must for women, men students consider women's employment as a luxury or a supplementary income. When majority of women students agree with the need for equal property rights of women with men, men students do not agree with it. Similarly in every aspect of social life such as economic participation, political leadership, professional education etc., women students seem to be ready for a take off to the heights while men students maintain traditional conservative mindsets regarding women's roles in the society.

In the second study, the female samples show a higher attitude score, steadily increasing from that of the first study, indicating that women of Kerala are moving towards a wide world of opportunities and achievements, breaking the traditional beliefs and social restrictions. These findings are in agreement with the results obtained by Sharma [13], way back in 1990 in her empirical study on 200 working women in Delhi belonging to different categories of professions that having education and employment in their credit, the working women have a different view about the existing society and that majority of the women after completing their education develop a tendency to seek a job.

The traditional mindsets of youngsters can have negative implications on the work participation and economic advancement of women in the present social context. Once the spouse maintains unfavourable attitudes towards the employment of the partner, it can affect her work participation rate in several ways. Decisions as whether to join the work force, the nature of work to be taken up and whether to continue with it amidst the work-family conflicts all depend on the nature and extent of spousal support. The rising atrocities against girls and women are also factors that restrict women's mobility and employment.

\section{Conclusion}

Women's work participation is not only a requirement for personal advancement but also to fuel the economic performance of communities, nations and the world. While on the global scenario, women workforce 
is considered as a key to the economic growth of $21^{\text {st }}$ century, the economic participation of women in India and especially that of Kerala is far from satisfactory. The negative attitude of boys to women's employment is to be considered as a barrier and serious threat in this direction. Even after getting educated, our boys continue to be traditional in their outlooks on gender roles of women and women's employment. When a father, brother or a husband holds back a daughter, sister or a wife from engaging in productive employment, the female work participation rate is likely to show this declining trend in the coming years also. Though a girl is having positive and progressive attitudes towards employment, her struggle to get employed will be hard once she marries a boy with negative attitude towards women's employment. Because in the present patriarchal social set up, majority of girls continue to be powerless in their marital life in spite of being successful decision takers as daughters and sisters. Whether such differences between the progressive outlook of girls and traditional outlook of boys contribute to the increasing divorce rates among youngsters is a matter to be subjected to further research. In order to change the deep rooted perceptions regarding gender roles and life goals of women, effective interventions in the socialization process in favour of women's emancipation is required. The family, education system, religion and media all have to take combined efforts to break the stereotypes and reform the outdated laws, customs and values that serve as barriers to women's economic advancement and development.

\section{References}

[1]. S. Mazumdar and M Guruswamy, Female labour force participation in Kerala- Problems and Prospects. Paper presented at the Annual Meeting Program Population Association of America, Los Angeles, California, March (2006).

[2]. Census data 1991, $2001 \& 2011$. Directorate of Census Operations, Kerala

[3]. Census data 1991, $2001 \& 2011$. Directorate of Census Operations, India

[4]. M. Kuruvilla, Discrimination against girl child - The trajectory of missing girls (New Delhi: Gyan Publishing House, 2011).

[5]. C.K. Holahan and Gilbert, Inter role conflict for working women: Career versus jobs. Journal of Applied Psychology, 64 (1), 1979 , 86-90. Retrieved from http : dyuthi.cusat.ac.in/xmlui/Bitstream/handle/purl/1846/Dyuthi-T0002.pdf? sequence=1.

[6]. M. Baker, Motherhood, employment and the "child penalty". Women's Studies, Vol.33 (1), $215-224$. Retrieved from http://dx.doi.org/10.1016/j.wsif. 2010.01.004.

[7]. R. Beaujot, Earning and Caring in Canadian Families. (Peterborough, Ontario: The Broadview Press, 2000).

[8]. R.H. Bassett, Parenting and Professoring (Vanderbilt : University Press, 2005).

[9]. Bracken, J. K., Allen and D. K. Dean (Eds.), The balancing act: Gendered perspectives in faculty roles and work lives (Sterling, Virginia: Stylus Publishing, 2006).

[10]. S.M. Desai, D. Chugh and A. Brief, Marriage structure and resistance to the gender revolution in the workplace, Social Science Electronic Publishing, Inc. Retrieved from http://ssm.com/abstract=2018259, 2012.

[11]. M. Kuruvilla and P. Usha, Attitude towards women's employment: Study on a university sample. Journal of Psychological Researches, 1999, Vol. 43 (2), 1999, 61-65.

[12]. M. Kuruvilla and P. Usha, A scale to measure attitude towards women's employment, Journal of Community Guidance and Research, 2000, Vol.17 (2), 2000, 191-194.

[13]. A. Sharma, Modernization and status of working women in India (New Delhi: Mittal Publications, 1990).

[14]. M. Kuruvilla, Gender studies components in teacher training: An essential requirement for teacher empowerment in the $21^{\text {st }}$ century. International Journal of Education and Psychological Research, Vol. 2 (2), 2013, 46-50. 